\title{
EVALUATION OF THE MORTALITY RATE ONE YEAR AFTER HIP FRACTURE AND FACTORS RELATING TO DIMINISHED SURVIVAL AMONG ELDERLY PEOPLE
}

Guilherme Ricci', Maurício Portal Longaray², Ramiro Zilles Gonçalves ${ }^{3}$, Ary da Silva Ungaretti Neto ${ }^{3}$, Marislei Manente ${ }^{4}$, Luíza Barbosa Horta Barbosa ${ }^{5}$

\begin{abstract}
Objective: To evaluate the mortality rate after one year and correlated preoperative factors, among patients with hip fractures. Methods: We prospectively studied 202 out of a total of 376 patients with a diagnosis of hip fracture who were admitted to the Hospital Cristo Redentor, between October 2007 and March 2009. The database with the epidemiological analysis was set up during their hospitalization, and follow-up data were obtained preferentially by phone. Results: The
\end{abstract}

overall mortality rate after one year of follow-up was $28.7 \%$ or 58 deaths, among which 11 (5.45\%) occurred during hospitalization. Fractures were more prevalent among women (71.3\%) and rare among blacks (5\%). Among the comorbidities, dementia and depression showed a statistically significant reduction in survival ( $\mathrm{p}=0.018$ and 0.007 , respectively). Conclusion: The mortality rate after one year of follow-up was $28.7 \%$. Dementia and depression increased this rate.

Keywords - Aged; Hip Injuries; Mortality

\section{INTRODUCTION}

Hip fractures continue to be one of the commonest and most devastating traumatic injuries among the geriatric population ${ }^{(1)}$. They occur mainly in the peritrochanteric region and may be associated with both high and low-energy trauma. The latter is more common among the elderly ${ }^{(2)}$. Hip fractures affect females more frequently and, although these fractures present good consolidation, they are associated with high rates of morbidity and mortality ${ }^{(3,4)}$.

In the United States, approximately 250,000 hip fractures occur every year, with an annual cost of around nine billion dollars ${ }^{(5,6)}$. One study suggested that the hospitalization of patients with hip fractures accounted for approximately $13 \%$ of total hospital expenditure on adults in Brazil in 2004 ${ }^{(7)}$.

In addition to the social losses resulting from fe- moral fractures, elderly people have lower functional reserves and present large numbers of associated chronic diseases. At the time of suffering the fracture, $70 \%$ of these patients have at least two other diseases. Thus, elderly people are much more subject to complications, both during the immediate postoperative period and later on ${ }^{(8)}$.

Studies in developed countries have suggested that certain preoperative factors are associated with higher mortality rates among patients presenting hip fractures on admission, for example: nonwhite color ${ }^{(3,9-12)}$, advanced age ${ }^{(11,13-15)}$, presence of dementia ${ }^{(16-18)}$, male sex ${ }^{(13,19,20)}$, clinical comorbidities ${ }^{(11,14,16,21,22)}$ and delirium $^{(18,23,24)}$.

In view of the importance that fractures of the proximal femur have for society, our aim was to determine the mortality rate and preoperative factors related

1 - Orthopedist at the Orthopedics and Traumatology Service, Hospital Regina, Novo Hamburgo, RS, Brazil.

2 - Orthopedist at Conceição Children's Hospital (HCC) (a unit of the Conceição Hospital Group), Porto Alegre, RS, Brazil.

3 - Orthopedist at the Orthopedics and Traumatology Service, Hospital Cristo Redentor (a unit of the Conceição Hospital Group), Porto Alegre, RS, Brazil.

4 - General Clinician at Hospital Cristo Redentor (a unit of the Conceição Hospital Group), Porto Alegre, RS, Brazil.

5 - Undergraduate Student in the $11^{\text {th }}$ Semester of the Medical Course, Lutheran University of Brazil, Canoas, RS, Brazil

Work performed at the Orthopedics and Traumatology Service, Hospital Cristo Redentor (a unit of the Conceição Hospital Group), Porto Alegre, RS, Brazil.

Correspondence: Rua Quintino Bocaiúva 100, ap. 501, 93510-270 Novo Hamburgo, RS. E-mail: riccicolorado@yahoo.com.br.

Work received for publication: August 30, 2011; accepted for publication: October 25, 2011.

The authors declare that there was no conflict of interest in conducting this work 
to such fractures, over the first year of follow-up after hip fractures among elderly people treated at Hospital Cristo Redentor, in Porto Alegre, between October 2007 and March 2009.

\section{MATERIAL AND METHODS}

A prospective study was conducted on 202 patients of both sexes over the age of 60 years, out of the total of 376 patients with a diagnosis of hip fracture (femoral neck, transtrochanteric or subtrochanteric) who were admitted to Hospital Cristo Redentor between October 2007 and March 2009, with any clinical cognitive or mental state, who remained eligible. Patients under the age of 60 years, those with pathological fractures and those who could not be contacted by telephone (no telephone number in the medical file or no telephone number for messages) were excluded.

While the patients were still in hospital, a database was set up, with an analysis on their epidemiological profile consisting of age, sex, date of hospitalization, type of fracture, side of the fracture, type of treatment, any previous arthroplasty on the hip and any presence of the following comorbidities: anemia, systemic arterial hypertension (SAH), heart diseases, lung diseases, rheumatoid arthritis, diabetes mellitus (DM), major depression, upper airway infection, urinary tract infection, thyroid diseases and dementia.

In the neuropsychiatric evaluation, we sought to detect the presence of depression through applying the diagnostic criteria of the American Psychiatric Association ${ }^{(25)}$ and the criteria of the Geriatric Depression Scale ${ }^{(26)}$. In evaluating dementia, we used the Mini-Mental State Examination ${ }^{(27)}$ and the diagnostic criteria of the American Psychiatric Association $^{(28)}$.

We obtained follow-up data preferentially over the telephone, from the medical files or at additional consultations. We often contacted family members or the patients themselves.

The time until death was calculated using the date of death supplied by the family when a telephone contact was made.

We used SPSS version 17.0, with a statistical significance level of $5 \%(p \leq 0.05)$. The Log-Rank test was used, and the analysis on the survival curve was done using the Kaplan-Meier curve.

\section{RESULTS}

Regarding the patients' profile (Table 1), the gender ratio was 2.48 (women to men). The left side predominated slightly as the fracture location (53.5\%). Only $5 \%$ of the patients had black skin color.

The patients' mean age (Table 2) was 79.15 years, with a standard deviation of 8.68. The male patients were older on average, with an age of 80.13 years (standard deviation \pm 8.55 ), whereas the mean was 76.72 years (standard deviation \pm 9.89 ) for the females. With regard to stratification according to age, the means and group compositions are presented in Table 2.

The fractures were categorized according to the fracture line location: trochanteric, subtrochanteric or femoral neck fractures (Table 3 ).

Regarding treatment (Table 4), the following were performed: 29 cases $(14.5 \%)$ of cemented total hip arthroplasty; 40 cases (19.8\%) of partial hip arthroplasty; 99 cases (49\%) of osteosynthesis using the Dynamic Hip Screw $\left(\mathrm{DHS}^{\circledR}\right) ; 15$ cases $(7.4 \%)$ of osteosynthesis using the Dynamic Condylar Screw (DCS $\left.{ }^{\circledR}\right)$; five cases $(2.5 \%)$ of osteosynthesis using the Proximal Femoral Nail $\left(\mathrm{PFN}^{\circledR}\right)$; and 11 cases $(5.4 \%)$ of osteosynthesis using cannulated screws $(7.0 \mathrm{~mm})$. Three patients $(1.5 \%)$ who were not in an adequate clinical state to undergo surgery were treated conservatively.

The presence of the following comorbidities was evaluated preoperatively: anemia, $\mathrm{SAH}$, heart diseases, lung diseases, rheumatoid arthritis, DM, psychiatric disease, upper airway infection, urinary tract infection, thyroid diseases and dementia (Table 5).

\begin{tabular}{l|c|c} 
Table 1 - Patients' profile. \\
\hline Gender & 144 women $(71.3 \%)$ & 58 men $(28.7 \%)$ \\
\hline Color & 192 whites $(95 \%)$ & 10 blacks $(5 \%)$ \\
\hline Side & 94 right $(46.5 \%)$ & 108 left $(53.5 \%)$ \\
\hline
\end{tabular}

Table 2 - Age profile of the men and women (means and standard deviations).

\begin{tabular}{c|c|c}
\hline $\begin{array}{c}\text { Age } \\
\text { group }\end{array}$ & Women & Men \\
\hline $60-69$ & $17($ mean $=66.52 \pm 5.65 \mathrm{SD})$ & $13($ mean $=65.69 \pm 4.24 \mathrm{SD})$ \\
\hline $70-79$ & $52($ mean $=74.76 \pm 6.36 \mathrm{SD})$ & $25($ mean $=74.64 \pm 6.36 \mathrm{SD})$ \\
\hline $80->$ & $75($ mean $=86.93 \pm 13.43 \mathrm{SD})$ & $20($ mean $=86.5 \pm 10.60 \mathrm{SD})$ \\
\hline Total & 144 & 58 \\
\hline & Mean $=76.72 \pm 9.89 \mathrm{SD}$ & Mean $=80.13 \pm 8.55 \mathrm{SD}$ \\
\hline
\end{tabular}

Mean age for the whole group $=79.153$ years;

Standard deviation: 8.68;

$\mathrm{N}$ total $=202$

$\mathrm{SD}=$ standard deviation 
Table 3 - Anatomical location of the fractures.

\begin{tabular}{c|c|c}
\hline Type of fracture & Number of cases & Percentage \\
\hline Trochanteric & 96 & $47.5 \%$ \\
\hline Femoral neck & 87 & $43.1 \%$ \\
\hline Subtrochanteric & 19 & $9.4 \%$ \\
\hline
\end{tabular}

Table 4 - Treatment performed.

\begin{tabular}{c|c|c}
\hline Type of operation performed & Number & Percentage \\
\hline Total hip arthroplasty & 29 & 14.5 \\
\hline Partial arthroplasty & 40 & 19.8 \\
\hline Synthesis - DHS 135० & 99 & 49 \\
\hline Synthesis - DCS 95० & 15 & 7.4 \\
\hline Synthesis - PFN & & 2.5 \\
\hline Cannulated screws $7.0 \mathrm{~mm}$ & 5 & 5.4 \\
\hline Conservative & 11 & 1.5 \\
\hline
\end{tabular}

Table 5 - Comorbidities present preoperatively.

\begin{tabular}{c|c|c}
\hline Diseases & Absent & Present \\
\hline Anemia & $173(85.6 \%)$ & $29(14.4 \%)$ \\
\hline SAH & $73(36.1 \%)$ & $129(63.9 \%)$ \\
\hline Heart diseases & $138(68.3 \%)$ & $64(31.7 \%)$ \\
\hline Lung diseases & $182(90.1 \%)$ & $20(9.9 \%)$ \\
\hline Rheumatoid arthritis & $197(97.5 \%)$ & $5(2.5 \%)$ \\
\hline DM & $158(78.2 \%)$ & $44(21.8 \%)$ \\
\hline Psychiatric disease & $155(76.7 \%)$ & $47(23.3 \%)$ \\
\hline Upper airway infection & $185(91.6 \%)$ & $17(8.4 \%)$ \\
\hline Urinary tract infection & $178(88.1 \%)$ & $24(11.9 \%)$ \\
\hline Thyroid disease & $194(96 \%)$ & $8(4 \%)$ \\
\hline Dementia & $172(85.1 \%)$ & $30(14.9 \%)$ \\
\hline
\end{tabular}

Fourteen patients $(6.9 \%)$ had undergone previous hip arthroplasty: nine cases $(4.45 \%)$ because of a fracture and five cases $(2.45 \%)$ because of arthrosis.

The total mortality rate after one year of followup was $28.7 \%$, i.e. 58 deaths, out of the total of 202 patients. The total mortality rate after two years was $41.8 \%$, i.e. 85 deaths. Eleven patients $(5.44 \%)$ died while in hospital. The median length of follow-up of the cases was 20.7 months (95\% CI: 19.1 to 22.2 ), and 77 deaths $(38.1 \%)$ occurred over this period.

The survival rates with their respective confidence intervals are presented in Table 6. Figure 1 demonstrates the survival analysis using the Kaplan-Meier curve.
Table 6 - Survival rates.

\begin{tabular}{c|c|c}
\hline Time & Survival (\%) & $95 \%$ Cl \\
\hline 3 months & 86.1 & 81.4 to 90.8 \\
\hline 6 months & 79.7 & 74.2 to 85.2 \\
\hline 9 months & 74.8 & 68.7 to 80.9 \\
\hline 12 months & 71.3 & 65.0 to 77.6 \\
\hline 15 months & 68.7 & 62.2 to 75.2 \\
\hline 18 months & 64.0 & 57.1 to 70.9 \\
\hline 21 months & 61.4 & 54.3 to 68.5 \\
\hline 24 months & 58.2 & 50.6 to 65.8 \\
\hline
\end{tabular}

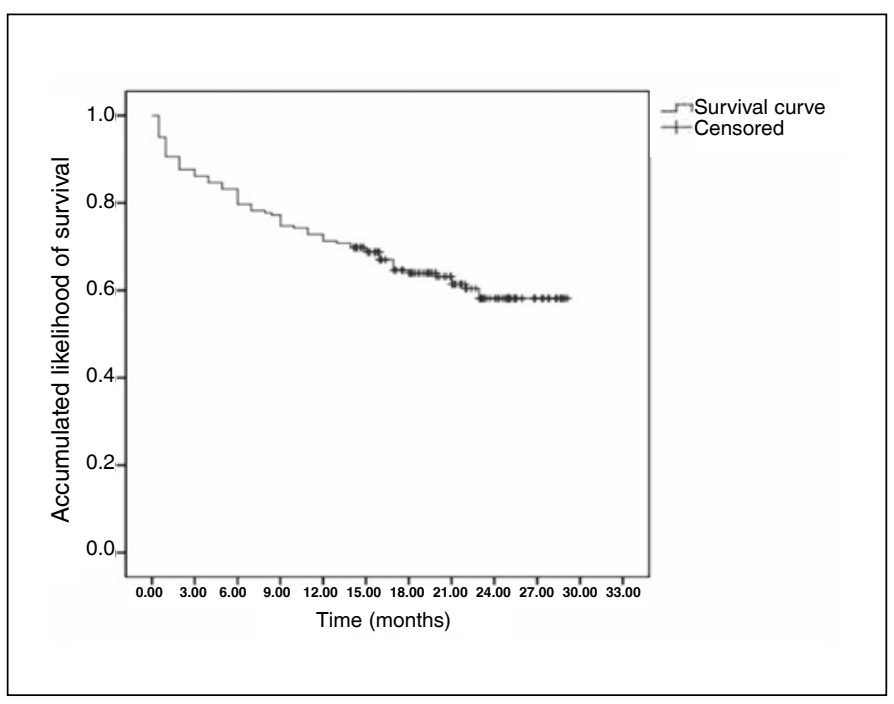

Figure 1 - Survival analysis by means of Kaplan-Meier curve.

Separate analysis on the male and female genders did not show any statistically significant differences on the survival curve over the course of time. Analysis on the type of fracture and the type of surgery performed also did not demonstrate any statistical significance in relation to reduced survival: there was only a trend towards a higher death rate for the trochanteric and subtrochanteric fracture types $(p=0.054)$, in comparison with femoral neck fractures.

In analyzing the survival curve stratified according to age groups (60-69 years, 70-79 years and 80 years and over), we did not find any statistically significant difference $(p=0.090)$. In the group of patients aged 80 years and over, we only found a greater tendency for the survival curve to be reduced.

Among the comorbidities evaluated, anemia, SAH, heart diseases, lung diseases, rheumatoid arthritis, DM, 
upper airway infection, urinary tract infection and thyroid diseases did not demonstrate any reductions in the respective survival curves in relation to their presence or absence among the patients in this study.

Among the patients who had previously undergone hip arthroplasty, independent of whether this was due to a fracture or to arthrosis, there was no greater mortality rate in comparison with the patients without this condition.

Analysis on the presence of dementia prior to the fracture occurrence showed that there was a statistically significant lower survival rate among the patients with dementia $(\mathrm{p}=0.018)$, as demonstrated in Figure 2. There was also a statistically significant reduction $(p=0.007)$ in the survival of the patients with a diagnosis of depression prior to hospitalization (Figure 3).

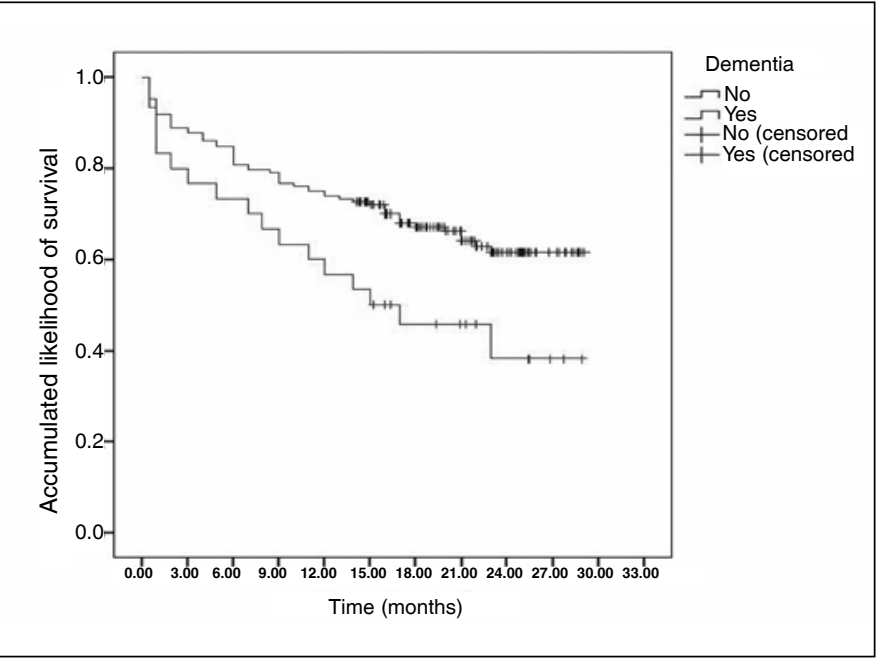

Figure 2 - Reduction in survival among patients with dementia prior to fracture.

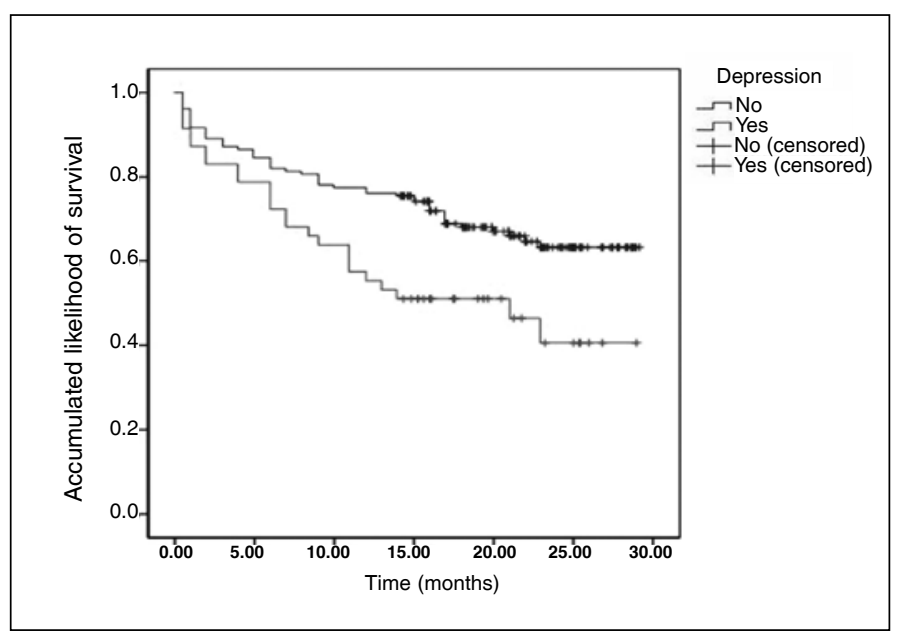

Figure 3 - Reduction in survival among patients with a diagnosis of major depression prior to fracture.

\section{DISCUSSION}

Hip fractures are common among elderly people and are associated with considerable morbidity and mortality ${ }^{(3,4)}$. The mortality rates among geriatric patients show that fractures of the proximal femur have a real and important influence on these patients' survival, especially if comparisons are made with the rates encountered among the population without fractures ${ }^{(14)}$.

The mortality rate one year after the occurrence of a fracture in the proximal extremity of the femur in elderly individuals ranges from 14 to $36 \%$, according to different studies $^{(3,13,14,18,22,29)}$, which reflects the heterogeneity of the populations studied and the differences in care standards. In our group of patients, the total mortality rate after one year of follow-up was $28.7 \%$ or 58 deaths.

The mortality rates during hospitalization present great variability in the literature ${ }^{(13,14,22)}$. While American studies have demonstrated rates of $1.6 \%$ and $1.8 \%{ }^{(30,31)}$, recent Brazilian studies have found rates of $6.5 \%$ and $8.9 \%{ }^{(3,13)}$. The mortality rate during hospitalization was $5.45 \%$ (11 deaths) in our study.

The present study showed that femoral fractures predominantly occurred in women $(71.3 \%)$ and that the frequency was relatively low among blacks (only $5 \%$ ). This is in line with the epidemiological profile of osteoporosis and its clinical manifestation of fractures of the proximal femur, which is proportionally greater among white postmenopausal women ${ }^{(3,9-12)}$.

With regard to gender, there was no difference in the survival curve over the course of time. While some studies have presented greater mortality rates among elderly men ${ }^{(13,19,20)}$, others have not associated higher rates with the male population ${ }^{(22,32)}$. Thus, it can be seen that there is some controversy regarding the gender-based prevalence of mortality subsequent to fractures of the proximal femur.

For most hip fractures, the treatment usually indicated is surgical. Conservative treatment is indicated only for some fractures classified as incomplete or without displacement ${ }^{(14)}$. Parker and Gurusamy ${ }^{(33)}$ conducted a systematic review in 2006, comparing total arthroplasty and internal fixation in cases of intracapsular fractures in elderly individuals. They selected 17 studies and did not find any significant differences in mortality rates. Likewise, we did not observe any significant differences in the survival curves among patients in this study regarding the sur- 
gical procedures, and this result is in agreement with previous reports $^{(3,13,15,34,35)}$.

In analyzing the types of fracture (trochanteric, subtrochanteric or femoral neck), we only found a tendency towards greater mortality in the groups of patients with trochanteric or subtrochanteric fractures. Patients with intracapsular fractures present significantly better survival than do those with extracapsular fractures $^{(4)}$. Despite this, our results are in agreement with the study by Karagiannis et $\mathrm{al}^{(32)}$, who observed similar mortality rates after one year $(p=0.112)$, and that only intertrochanteric fractures with five years of evolution $(p=0.01)$ or 10 years of evolution $(p=0.001)$ presented significantly greater rates.

Some authors have reported an association between age and mortality subsequent to a fracture of the proximal femur. Patients over the age of 80 years present a greater likelihood of death after this type of fracture, in comparison with individuals in the age group from 60 to 80 years ${ }^{(11,13-15)}$. In stratifying our patients according to age group, we only found a tendency towards greater reduction in survival among the patients aged 80 years and over.

Although many authors have reported that co-

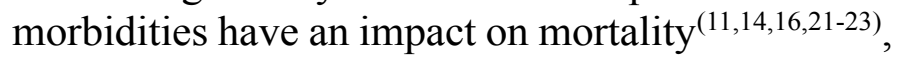
most of the clinical comorbidities evaluated among our patients did not demonstrate any reduction in the survival curve. Among the pathological conditions analyzed that did not show statistical significance were the following: anemia, SAH, heart diseases, lung diseases, rheumatoid arthritis, DM, upper airway infection, urinary tract infection and thyroid diseases.

Pereira et $\mathrm{al}^{(3)}$ also did not observe any association between certain comorbidities and higher mortality rates subsequent to hip fractures among elderly individuals. According to these authors, this finding may have been related to the data gathering, given that this was from hospital graphics in which the comorbidity was recorded as "present" or "absent", without specifying the level of severity. Since the data for our study were gathered in a similar manner, we can put forward the possibility that the same thing could have occurred.

Penrod et $\mathrm{al}^{(16)}$, Souza et $\mathrm{al}^{(17)}$ and Cunha and Veado $^{(18)}$ demonstrated that dementia had a negative impact on the survival, and this was confirmed in our series $(p=0.018)$. Regarding the presence of depression, we observed that the survival of patients with a diagnosis of depression prior to hospitalization was significantly lower $(p=0.007)$, and this result was in line with the findings from other studies ${ }^{(18,23,24)}$.

The public-health impact of hip fractures is enormous. This impact is demonstrated by the high morbidity-mortality and the increasingly high costs related to such fractures. It is fundamentally important to implement effective strategies both for treating and for following up these individuals. Thus, the present study is of considerable importance, given that it covers factors of relevance to the prognosis for this pathological condition. The conclusion reached is in line with the literature.

\section{CONCLUSION}

The mortality rate over the first year of follow-up subsequent to occurrences of hip fractures among the patients in this study was $28.7 \%$. With regard to the patient profile, this study showed that the femoral fractures occurred predominantly in women $(71.3 \%)$, with low frequency among blacks (5\%). Lastly, we found that the survival of patients with diagnoses of dementia or depression was statistically significantly lower $(\mathrm{p}=0.018$ and $\mathrm{p}=0.007$, respectively).

\section{REFERENCES}

1. Lustosa LP, Bastos EO. Fraturas proximais do fêmur em idosos: qual o melhor tratamento? Acta Ortop Bras. 2009;17(5):309-12.

2. Siqueira FV, Facchini LA, Piccini RX, Tomasi E, Thumé E, Silveira DS et al. Prevalência de quedas em idosos e fatores associados. Rev Saúde Pública. 2007;41(5):749-56

3. Pereira SRM, Puts MTE, Portela MC, Sayeg A. The Impact of Prefracture and Hip Fracture Characteristics on Mortality in Older Persons in Brazil. Clin Orthop Relat Res 2010; 68(7):1869-83.

4. Johnston AT, Barnsdale L, Smith R, Duncan K, Hutchison JD. Change in long-term mortality associated with fractures of the hip: evidence from the scottish hip fracture audit. J Bone Joint Surg Br. 2010;92(7):989-93.

5. Bhandari M, Devereaux PJ, Tornetta P 3rd, Swiontkowski MF, Berry DJ, Haidukewych $G$, et al. Operative management of displaced femoral neck fractures in elderly patients. An international survey. J Bone Joint Surg Am. 2005;87(9):2122-130.

6. Donegan DJ, Gay AN, Baldwin K, Morales EE, Esterhai JL Jr, Mehta S. Use of medical comorbidities to predict complications after hip fracture surgery in the elderly. J Bone Joint Surg Am. 2010; 92(4):807-13.

7. Peixoto SV, Giatti L, Afradique ME, Lima-Costa MF. Custo das internações hospitalares entre idosos brasileiros no âmbito do Sistema Único de Saúde. Epidemiol Serv Saúde. 2004;13(4):239-46. 
8. Van Balen R, Steyerberg EW, Polder JJ, Ribbers TL, Habbema JD, Cools HJ. Hip fracture in elderly patients: outcomes for function, quality of life, and type of residence. Clin Orthop Relat Res. 2001;(390):232-43.

9. Ramalho AC, Lazaretti-Castro M, Hauache O, Vieira JG, Takata E, Cafalli F, et al. Osteoporotic fractures of proximal femur: clinical and epidemiological features in a population of the city of São Paulo. São Paulo Med J. 2001; 119(2):48-53.

10. Rocha MA, Azer HW, Nascimento VG. Evolução funcional nas fraturas da extremidade proximal do fêmur. Acta Ortop Bras. 2009;17(1):17-21.

11. Mesquita GV, Abreu Lima MALT, Santos AMR, Alves EM, Brito JNPO, Martins MCC. Morbimortalidade em idosos por fratura proximal do fêmur. Texto Contexto Enferm Florianópolis. 2009;18(1):67-73.

12. Richmond J, Aharonoff GB, Zuckerman JD, Koval KJ. Mortality risk after hip fracture. J Orthop Trauma. 2003;17(8 Suppl):S2-5.

13. Garcia R, Leme MD, Garcez-Leme LE. Evolution of brazilian elderly with hip fracture secondary to a fall. Clinics. 2006;61(6):539-44.

14. Sakaki MH, Oliveira AR, Coelho FF, Lema LEG, Suzuki I, Amatuzzi MM. Estudo da mortalidade na fratura do fêmur proximal em idosos. Acta Ortop Bras. 2004;12(4):242-49

15. Dzupa V, Bartonicek J, Skala-Rosenbaum J, Prikazsky V. Mortality in patients with proximal femoral fractures during the first year after the injury. Acta Chir Orthop Traumatol Cech. 2002;69(1):39-44.

16. Penrod JD, Litke A, Hawkes WG, Magaziner J, Doucette JT, Koval KJ, et al The association of race, gender, and comorbidity with mortality and function after hip fracture. J Gerontol A Biol Sci Med Sci. 2008;63(8):867-72.

17. Souza RC, Pinheiro RS, Coeli CM, Camargo KR Jr. Aplicação do índice de comorbidade de Charlson (ICC) no ajuste de risco da mortalidade após fratura proximal de fêmur em idosos: análise da importância dos diagnósticos secundários. Cad Saúde Pública. 2008;24(2):315-22.

18. Cunha U, Veado MAC. Fratura da extremidade proximal do fêmur em idosos: independência funcional e mortalidade em um ano. Rev Bras Ortop. 2006;41(6):195-99.

19. Fierens J, Broos PLO. Quality of life after hip fracture surgery in the elderly. Acta Chir Bel. 2006;106(1):393-96.

20. Wehren LE, Hawkes WG, Orwig DL, Hebel JR, Zimmerman SI, Magaziner J Gender differences in mortality after hip fracture: the role of infection. J Bone Miner Res. 2003;18(12):2231-7.

21. Farahmand BY, Michaelsson K, Ahlbom A, Ljunghall S, Baron JA. Swedish Hip Fracture Study Group. Survival after hip fracture. Osteoporos Int. 2005;16(12):1583-590.
22. Franzo A, Francescutti C, Simon G. Risk factors correlated with post-operative mortality for hip fracture surgery in the elderly: a population-based approach. Eur J Epidemiol. 2005;20(12):985-91.

23. Nightingale S, Holmes J, Mason J, House A. Psychiatric illness and mortality after hip fracture. Lancet. 2001;357(9264):1264-5.

24. Vestergaard $P$, Rejnmark $L$, Mosekilde $L$. Has mortality after a hip fracture increased? J Am Geriatr Soc. 2007;55(11):1720-6.

25. Mood disorders. In: American Psychiatric Association. Diagnostical and statistical manual of mental disorders. 4th ed. Washington: American Psychiatric Association; 1994. p.317-91

26. Yesavage JA, Brink TL, Rose TL, Lum O, Huang V, Adey M, Leirer VO. Development and validation of a geriatric depression screening scale: a preliminary report. J Psychiatr Res.1983;17(1):37-49.

27. Folstein MF, Folstein SE, McHugh PR. "Mini-mental state". A practical method for grading the cognitive state of patients for the clinician. J Psychiatr Res. 1975;12(3):189-98.

28. Deleirum, Dementia, and Amnestic and Other Cognitive Disorders. In: American Psychiatric Association. Diagnostical and Statistical Manual of Mental Disorders. 4th ed. Washington: American Psychiatric Association; 1994. p.123-63.

29. Jiang HX, Majumdar SR, Dick DA, Moreau M, Raso J, Otto DD, Johnston DW. Development and initial validation of a risk score for predicting in-hospital and 1-year mortality in patients with hip fractures. J Bone Miner Res. 2005;20(3):494-00.

30. Cornwall R, Gilbert MS, Koval KJ, Strauss E, Siu AL. Functional outcomes and mortality vary among different types of hip fractures: a function of patient characteristics. Clin Orthop Relat Res. 2004;(425):64-71.

31. Hannan EL, Magaziner J, Wang JJ, Eastwood EA, Silberzweig SB, Gilbert M, et al. Mortality and locomotion 6 months after hospitalization for hip fracture: risk factors and risk-adjusted hospital outcomes. JAMA. 2001;285(21):2736-742.

32. Karagiannis A, Papakitsou E, Dretakis K, Galanos A, Megas P, Lambiris E et al. Mortality rates of patients with a hip fracture in a southwestern district of Greece: ten-year follow-up with reference to the type of fracture. Calcif Tissue Int. 2006;78(2):72-7.

33. Parker MJ, Gurusamy K. Internal fixation versus arthroplasty for intracapsular proximal femoral fractures in adults. Cochrane Database Syst Rev. 2006;(4):CD 001708.

34. Pinheiro RS, Coeli CM, Vidal EI, Camargo Júnior KR. Mortalidade após fratura do quadril. Cad Saúde Coletiva. 2006;14:327-36

35. Bhandari M, Devereaux PJ, Swiontkowski MF, Tornetta P 3rd, Obremskey W, Koval KJ et al. Internal fixation compared with arthroplasty for displaced fractures of the femoral neck. A meta-analysis. J Bone Joint Surg Am. 2003;85(9):1673-81. 